Síntese - Rev. de Filosofia

v. 37 N. 119 (2010): 383-406

\title{
A RELAÇÃo ÉTICA COMO RELIGIÃo EM EMMANUEL LÉVINAS
}

(The ethical relation as religion in Emmanuel Lévinas)

\author{
Márcio Antônio de Paiva* \\ José Geraldo Estevam**
}

Resumo: $\mathrm{O}$ texto apresenta o sentido original da religião desvelado pela relação ética na qual o rosto do outro manifesta o vestígio de Deus que vem à ideia sem que esta consiga tematizá-lo ou conhecê-lo. Nessa perspectiva, a filosofia deve ser desdita constantemente por um dizer ético, conforme o propõe Lévinas.

Palavras-chave: Ética, relação, religião, sentido, dizer.

Abstract: The paper presents the original meaning of religion unveiled by the ethical relation in which the face of the other expresses the trace of God that emerges without, however, making it possible to thematize or to know Him. From this perspective, and as it is proposed by Levinas, philosophy must constantly be unsaid by an ethical saying.

Keywords: Ethics, relation, religion, meaning, saying.

\footnotetext{
* Doutor em filosofia pela Gregoriana de Roma e professor do Programa de Pós-Graduação em Ciências da Religião da PUC Minas. Artigo submetido a avaliação no dia 30/06/ 2010 e aprovado para publicação no dia 13/10/2010

** Mestre em Ciências da Religião pela Pontifícia Universidade Católica de Minas Gerais. Professor de Ensino Religioso no Colégio Santo Antônio, Belo Horizonte.
} 


\section{Introdução}

$\mathrm{A}$ filosofia de Emmanuel Lévinas (1906-1995), filósofo de origem ju daica, naturalizado francês, sinaliza para a importância de uma guinada da filosofia como forma de se superar a noção de um pensamento que acredita pensar mais do que pensa ${ }^{1}$. A partir desse pressuposto, este trabalho tem como objetivo apresentar os aspectos da proposta levinasiana que desvelam a relação ética como religião. Na perspectiva do filósofo lituano, a ética e, nesse caso, também a religião, é oriunda da socialidade e não da ontologia. Assim sendo, a religião não se confunde com a filosofia e nem com a teologia fundada no logos grego.

Nesse viés, a religião se constitui a partir de seu sentido ético pelo qual o outro é reconhecido enquanto outro e não como um alter ego. Outro identificado com o órfão, a viúva e o estrangeiro, como aqueles pelos quais o eu deve se colocar a serviço incondicionalmente. Como se vê, é pela relação entre o eu e o outro na sua alteridade infinita que a ética é entendida como religião.

Desvela-se, assim, a originalidade da religião que por meio da alteridade aponta para a responsabilidade como mandamento ético orientado para o outro que, em seu rosto, manifesta a presença de Deus enquanto vestígio do infinito que se cede à ideia ou ao pensamento. Rosto que na sua exterioridade e nudez características ao mesmo tempo é ordem e mistério: ordem, que impede o eu de matar o outro; e mistério, que o impossibilita de absorvê-lo ou abarcá-lo no si mesmo. Como será descrito neste trabalho, rosto que revela a glória do infinito enquanto dimensão transcendente de Deus e da filosofia como sabedoria do amor capaz de desdizer constantemente pela relação ética seus ditos ontológicos.

\section{O sentido original da religião}

A proposta filosófica de Lévinas apresenta uma originalidade na história, ao apontar a ética como precedente à ontologia, mesmo sem prescindir da filosofia e da razão, que passam a ser observadas sob novo sentido ${ }^{2}$. Nesse

\footnotetext{
${ }^{1}$ Vale conferir em Totalidade e Infinito, especialmente, na alínea B (Rosto e ética, p. 173183) da Seção III (Rosto e exterioridade p. 165-197), em que Lévinas discorre sobre o transbordamento do pensamento, ou seja, o pensamento que pensa mais do que pensa. RIBEIRO JÚNIOR (2005, p. 322) cita esta expressão de Lévinas ao se referir à irredutibilidade do outro ao eu enquanto entes separados.

${ }^{2}$ Sobre este novo sentido atribuído à filosofia e à razão e, por consequência, à ontologia na filosofia de Lévinas, Pivatto (2001b, p.227) sublinha que: A ontologia reaparece claramente, mas agora está como que inseminada pelo sentido ético. Surgem as teorias, os ditos, as sistematizações, porém sempre criticáveis, sempre atra-
} 
contexto, a ética concebida como filosofia primeira amplia significativamente a noção que se construiu sobre a alteridade, na tradição. Este reconhecimento garante ao outro o espaço que sistematicamente lhe foi negado, subjugando-o ao eu e à razão. Pela concepção de Lévinas

A alteridade que conta aqui está fora de toda caracterização do outro mediante a ordem ontológica e à margem de qualquer atributo; aparece como próxima numa proximidade que conta como sociabilidade que 'excita' através de sua alteridade pura e da simples relação que tentamos analisar sem recorrer às categorias que a dissimulam ${ }^{3}$.

Pela relação ética o outro não deve apenas ser respeitado e reconhecido, já que ela ultrapassa as teorias elaboradas filosófica, científica, religiosa, enfim, ontologicamente, no curso da história. Tal salto é possível, pois ao inverter a lógica da ontologia, Lévinas não apenas propõe o reconhecimento do outro através da relação ética, mas também possibilita outra forma de pensar, que permite conceber a religião para além da ontologia ou da razão. Luiz Carlos Susin ao descrever sobre este aspecto da filosofia levinasiana, diz que

A ética reúne em si o relacionamento social e o relacionamento religioso 'justos', sem ideologia e sem mito, relacionamento que é excepcional por este paradoxal caráter: sem comprometer a unicidade e a interioridade, coroa a subjetividade da responsabilidade aprofundando sua unicidade com responsabilidade e bondade, permitindo assim ser adulto, social e religiosamente ${ }^{4}$.

A partir desse pressuposto fica manifesto que, por meio da ética, Lévinas rompe com a concepção de religião associada à ontologia, a qual, ao submeter acriticamente o outro às suas tematizações, reduziu a relação ao pensamento. Esta ruptura, portanto, sinaliza uma filosofia aberta a outras formas de saber, que ultrapassa a ontologia e reconduz a religião para sua dimensão infinita, ou seja, para além dos dogmas que tentam aprisioná-la - enfim, reduzi-la às amarras das leis, como mais relevantes que o humano.

Assim, delineia-se a originalidade da religião numa ruptura com a ontologia e abertura para a ética. François Poirié descreve esta originalidade de forma a deixar claro como a relação ética constitui aquilo a que Lévinas denomina religião, a saber:

\footnotetext{
vessadas pela inquietude da proximidade, pois desde que uma medida se objetiva em lei ou código, o humano trepida a perigar e começa a injustiça. Por isso, a inspiração da responsabilidade assimétrica deve permanecer sempre como dizer frontal incontornável. ${ }^{3}$ [...] La alteridad que cuenta aquí está fuera de toda cualificación del otro mediante el orden ontológico y al margen de todo atributo; aparece como próxima en una proximidade que cuenta en tanto que sociabilidad que 'excita' a través de su alteridad pura y de la simple relación que hemos intentado analizar sin recurrir a las categorías que la disimulan. [...]. (LEVINAS, Emmanuel. De otro modo que ser: o más allá de la esencia. Salamanca: Ediciones Sígueme, 2003. p. 61.

${ }^{4}$ SUSIN, Luiz Carlos. O homem messiânico: uma introdução ao pensamento de Emmanuel Lévinas. Petrópolis: Vozes, 1984. p. 247.
} 
Ponto de partida da relação ética, 'ponto' que Lévinas situa ainda no espaço da metafísica, o face-a-face em que Eu encontro Outrem, no qual ele me faz face na impossibilidade de desvio, da esquiva, é esse momento primeiro, último e irredutível, que Lévinas chama religião ${ }^{5}$.

É interessante observar que a concepção levinasiana apresenta a religião compreendida como ética, pois é pela relação que se dá face-a-face entre eu e o outro, que ela transcende à ontologia. Logo, a alteridade oriunda da relação ética pressupõe uma abertura da razão para novas possibilidades que a façam encontrar-se não mais em si mesma, mas sim na socialidade, sem se autoanular. Constata-se, dessa forma, que a religião, para além das doutrinas institucionais de matriz dogmática e ontológica, constitui-se em ética.

\section{O sentido ético da religião}

A religião concebida na perspectiva levinasiana desperta no movimento das relações humanas, no acolhimento do outro a transcendência presente na própria imanência e não num mundo distante e insensível. Esta condição a torna livre das totalizações que tendem a aprisioná-la nos conceitos e distanciá-la, ao mesmo tempo, do Outro transcendente e do outro imanente, o que possibilita sua ruptura com a ontologia conforme o descreve Lévinas em Totalidade e Infinito:

A ruptura da totalidade não é uma operação de pensamento, obtida por simples distinção entre termos que se atraem ou, pelo menos, se alinham (...) Em vez de constituir com ele, como com um objeto, um total, o pensamento consiste em falar. Propomos que se chame religião ao laço que se estabelece entre o Mesmo e o Outro, sem constituir uma totalidade ${ }^{6}$.

Dessa forma, a religião em Lévinas abrange uma dimensão que ultrapassa o significado institucional que, ao longo da história, não apenas a transformou em conceito, mas, principalmente, transformou-a em totalidade. Levando em consideração, igualmente, que é pela relação ética que se revela a verdadeira face da religião, tanto sua condição imanente quanto sua dimensão de transcendência são garantidas pela relação que se tece entre eu e o outro. Segundo o filósofo A relação ética define-se, contra toda a relação com o sagrado, excluindo toda a significação que ela tomaria sem o conhecimento daquele que a mantém ${ }^{7}$.

${ }_{5}^{5}$ POIRIÉ, François. Emmanuel Lévinas: ensaio e entrevistas. São Paulo: Perspectiva, 2007. p. 38.

${ }^{6}$ LEVINAS, Emmanuel. Totalidade e infinito. Ensaio sobre a exterioridade. Trad.: José P. Ribeiro. Lisboa: Edições 70, 1980. p. 27-28.

${ }^{7}$ LEVINAS, Emmanuel. Totalidade e infinito. Ensaio sobre a exterioridade. Trad.: José P. Ribeiro. Lisboa: Edições 70, 1980. p. 65. 
A religião, portanto, vem da relação ética, do comprometimento com o outro, com a vida do outro, sem criar um mundo ideal, racionalizado e distante, desvinculado do chão da vida. A ética e a religião estão, assim, ligadas pela relação e pela alteridade, o que, a partir da concepção de ética como filosofia primeira, supõe uma religião que não deve se fundamentar na ontologia, mas sim na relação entre os homens. Por isso, a crítica de Lévinas à crosta conceitual acumulada historicamente na filosofia, dirige-se também à maneira como a religião foi concebida na tradição, como se pode constatar a seguir:

A face positiva da estrutura formal - ter a Ideia do Infinito - equivale no concreto ao discurso que se precisa como relação ética. Reservamos à relação entre o ser cá em baixo e o ser transcendente que não desemboca em nenhuma comunidade de conceito nem em nenhuma totalidade... o termo de religião ${ }^{8}$.

Ora, para Lévinas ${ }^{9}\left(1980\right.$, p. 65), a metafísica tem lugar nas relações éticas ${ }^{10}$, e não nos conceitos teológicos de matriz ontológica que paradoxalmente descaracterizou a religião, tornando-a obsoleta ao transpô-la para uma realidade distante das relações sociais. Por isso, a religião se constitui na relação entre os homens, já que

Há o recurso à noção de uma religião horizontal, que permanece sobre a terra dos homens e que deveria se substituir à vertical que aponta para o Céu, para se referir ao mundo, porque é a partir do mundo que se continua a pensar os próprios homens ${ }^{11}$.

Confirma-se, pois, que a relação ética pressupõe a originalidade da religião que, assim como a ética, torna-se pré-originária ao pensar, pois se abre para o infinito e não se prende à totalidade. Aliás, este talvez seja o maior equívoco da razão: acreditar que se possa reduzir o infinito. Neste caso, o infinito deixaria de ser infinito, pois estaria enclausurado dentro da consciência humana, que é quem pensa - ou, pelo menos, ousa acreditar - que pode pensar e conter o todo. A ética, ao contrário, está aberta para a transcendência e o infinito que se revelam na alteridade, no rosto do outro.

\footnotetext{
${ }^{8}$ LEVINAS, Emmanuel. Totalidade e infinito. Ensaio sobre a exterioridade. Trad.: José P. Ribeiro. Lisboa: Edições 70, 1980. p. 66.

${ }^{9}$ LEVINAS, Emmanuel. Totalidade e infinito. Ensaio sobre a exterioridade. Trad.: José P. Ribeiro. Lisboa: Edições 70, 1980. p. 65.

${ }^{10}$ Ribeiro Júnior descreve assim este novo lugar da metafísica na filosofia levinasiana: Essa nova concepção de metafísica, que se articula em torno da religião ética e da ética como religião, se opõe àquilo que a filosofia clássica atribuía à metafísica, como se ela fosse o fundamento da religião, ou o sentido do dever da ética. A metafísica será, antes de tudo, o lugar de uma relação com o Absolutamente Outro ou da verdade segundo a qual 'a ética é a via real'. Essa concepção de metafísica como 'intriga' do ético e do religioso, explica a aversão de Lévinas por qualquer forma de pensamento filosófico que promova o sistema e a totalidade. (RIBEIRO JÚNIOR, NILO. Sabedoria de amar: a ética no itinerário de Emmanuel Lévinas. São Paulo: Loyola, 2005. p. 211.).

${ }^{11}$ LEVINAS, Emmanuel. De Deus que vem à ideia. Trad.: Pergentino Stefano Pivatto. Petrópolis: Vozes, 2002. p. 147.
} 
Esta abertura da ética estendida à religião faz com que ambas se livrem das amarras das doutrinas filosóficas revestidas por uma teologia racional. E, para Lévinas, uma religião que não esteja associada à ética não deve assim ser denominada. A religião encontra seu significado, sua representação mais pura, na relação ética e não na razão que insiste em manter-se fechada para a exterioridade, como se detivesse o todo. Na proposta levinasiana

A totalidade e o amplexo do ser ou ontologia não detêm o segredo último do ser. A religião em que a relação subsiste entre o Mesmo e o Outro, a despeito da impossibilidade do Todo - a ideia do Infinito - é a estrutura última ${ }^{12}$.

Diante da mudança na qual a razão deve se abrir para outras possibilidades, a ética e a religião se tornam originárias, o que, de certa forma, liberta a razão de suas próprias amarras conceituais, podendo estender esta libertação à linguagem, à moral, enfim, a todos os elementos que porventura, também se acham presos pelas correntes racionais. Lévinas chega a afirmar que se a religião coincide com vida espiritual é necessário que a religião seja essencialmente ética ${ }^{13}$.

Para isso, ela precisa se desvincular da ontologia e da própria teologia como condição para cumprir sua função mais nobre: despertar o homem para uma antropologia ${ }^{14}$, que considera o humano para além do logos, e resgata sua sensibilidade e afetividade numa compreensão que considere a ética precedente ao pensamento, pois o vê na sua alteridade infinita. $\operatorname{Susin}^{15}$ retrata esta mudança proposta por Lévinas, ao destacar que a

'Religião' entendida como relação ética e diaconia não tem a ética como corolário e nem mesmo como condição - estágio que poderia ser superado - pois ética e religião coincidem. A relação ética, relação entre ab-solutos e socialidade autêntica, é a metafísica que cumpre a relação ao transcendente, meta-ontologia à qual corresponde uma meta-antropologia - se entendermos por antropologia o ser do homem, - uma antropologia que começa pelo outro homem e que chamará a sair da antropologia correlativa aos parâmetros do ser.

${ }^{12}$ LEVINAS, Emmanuel. Totalidade e infinito. Ensaio sobre a exterioridade. Trad.: José P. Ribeiro. Lisboa: Edições 70, 1980. p. 66.

${ }_{13}$... si la religión coincide con la vida espiritual es necesario que la religión sea esencialmente ética. LEVINAS, Emmanuel. Dificil Libertad. Ensayos sobre o judaismo. Trad.: Juan Haidar. Madrid: Caparrós Editores, 2004. p. 24.

${ }^{14}$ A esse respeito, Ribeiro Júnior, escreve que somente uma antropologia em que o homem aparece como sensibilidade, afetividade, corporeidade ou como 'amor não-érótico' é que permite compreender a nova semântica que a palavra 'ética' assume como 'responsabilidade' no pensamento ético de Lévinas. (RIBEIRO JÚNIOR, Nilo; VÁZQUEZ MORO, Ulpiano. A gênese da ética e da teologia na filosofia de Emmanuel Levinas. 1999. 69f. Tese de Doutorado - Centro de Estudos Superiores da Companhia de Jesus, Faculdade de Teologia. p. 34-35).

${ }^{15}$ SUSIN, Luiz Carlos. O homem messiânico: uma introdução ao pensamento de Emmanuel Lévinas. Petrópolis: Vozes, 1984. p. 249. 
Para elucidar esta proposta de Lévinas, na qual o que prevalece é a relação ética e não a religião no âmbito institucional, o próprio filósofo em Dificil Libertad faz referências aos cristãos (católicos) e muçulmanos que ajudaram a salvar a vida de judeus durante os horrores da Segunda Guerra, conforme descrito a seguir:

Israel se encontrou novamente no coração da história religiosa do mundo, fazendo explodir as perspectivas nas que se haviam encerrado as religiões constituídas, restabelecendo, nas consciências mais finas, o laço até então incompreensivelmente dissimulado entre o Israel de nossos dias e o Israel da Bíblia. No momento em que se temia esta experiência, cuja amplitude religiosa terá marcado para sempre o mundo, alguns católicos - leigos, sacerdotes, monjes - salvaram crianças e adultos judeus na França e fora da França; e sobre esta mesma terra, judeus ameaçados pelas leis raciais escutaram a voz de um príncipe muçulmano que nos acolheu sob sua insigne proteção ${ }^{16}$.

Estes são, portanto, exemplos fortes de uma situação em que as diferenças étnicas, religiosas, culturais, entre outras, dão prioridade à relação ética, em que o eu se arrisca para salvar a vida do outro, na sua condição de estrangeiro e diferente. A religião atinge, assim, seu significado mais elevado, sua verdadeira razão de ser, ou seja, sua transcendência e originalidade numa abertura total para o infinito, através do serviço ao outro. Nesse sentido é que se pode pensar que não há totalidade racional capaz de reduzir a ética e a religião ao todo, já que a relação prevalece sobre qualquer tematização totalizante.

\section{3. $O$ sentido universal ${ }^{17}$ da religião}

Conforme a descrição desenvolvida até aqui, a originalidade da religião está na relação ética de serviço ao outro, o que torna plausível a afirmação de que ela possui uma dimensão infinita. Dimensão que não a distancia da

\footnotetext{
${ }^{16}$ Israel se encontró nuevamente en el corazón de la historia religiosa del mundo, haciendo estallar las perspectivas en las que se habian encerrado las religiones constituidas, restableciendo, en las conciencias más finas, el lazo hasta entonces incomprensiblemente disimulado entre el Israel de nuestros as y el Israel de la Biblia. En el momento en el que se tenía esta experiencia, cuya amplitud religiosa habrá marcado para siempre al mundo algunos católicos - laicos, sacerdotes, monjes - salvaban niños y adultos judios en Francia y fuera de Francia; y sobre esta misma tierra judios amenazados por las leyes raciales escucharon la voz de un príncipe musulmán que nos acogió bajo su insigne protección. (LEVINAS, Emmanuel. Dificil Libertad. Ensayos sobre el judaismo. Trad.: Juan Haidar. Madrid: Caparrós Editores, 2004. p. 30).

${ }^{17}$ Vale dizer que universal aqui, não se refere à concepção de religião única e absoluta, mas sim da eleição como serviço e responsabilidade para com o outro, de acordo com o sentido atribuído por Lévinas em Difícil Liberdade p. 219-221. Sobre este assunto, vale conferir também a descrição feita por Ribeiro Júnior ((RIBEIRO JÚNIOR, NILO. Sabedoria de amar: a ética no itinerário de Emmanuel Lévinas. São Paulo: Loyola, 2005. p. 211.).
} 
vida, já que a responsabilidade para com o outro se dá nas relações cotidianas, no face a face entre eu e o outro que está próximo, numa proximidade que se manifesta na socialidade não apenas daquele que está visível, mas de toda a humanidade. A dimensão transcendente, assim, não distancia a religião da realidade.

Dessa maneira, Lévinas sinaliza para outro modo de compreensão das relações humanas, marcadas por uma dimensão para além dos interesses pessoais. Por isso, para além da razão totalizante que, por exemplo, ao representar o transcendente, acaba por acreditar que o abarcou dentro de si, o filósofo lituano acrescenta que

A conjuntura entre o Mesmo e o Outro, em que já se mantém a sua proximidade verbal, é o acolhimento de frente e de lado do Outro para mim. Conjuntura irredutível à totalidade, porque a posição de 'frente a frente' não é uma modificação do 'ao lado de... '. Mesmo quando tiver ligado Outrem a mim pela conjunção ' $\mathrm{e}$ ', esse Outrem continua a fazer-me frente, a revelar-se no seu rosto. A religião subtende esta totalidade formal ${ }^{18}$.

Verifica-se que a proposta de Lévinas se alicerça nas relações inter-humanas constituídas na abertura para o infinito, na qual a moral religiosa se sustenta no serviço e responsabilidade para o outro, de forma desinteressada, na qual a religião ultrapassa, por exemplo, as meras consolações que a maioria das religiões oferece a seus fiéis. Em Ética e Infinito, Philippe Nemo propõe a seguinte questão a Lévinas sobre este assunto: $A$ aproximação do Infinito é, pois, essencialmente, a mesma para todo o homem. Contudo, só as religiões particulares proporcionam aos homens consolações. A exigência ética é universal, mas a consolação seria um assunto de família? ${ }^{19}$

Ao responder-lhe, Lévinas sinaliza para a religião que não se confunde com o que dizem ou fazem as diversas religiões. De acordo com o filósofo a religião não é idêntica à filosofia, a qual não proporciona necessariamente as consolações que a religião sabe outorgar ${ }^{20}$. É nesse sentido que se desvela o sentido universal atribuído à religião pelo filósofo lituano, especialmente, ao judaísmo, conforme descrito a seguir:

O papel desempenhado pela ética na relação religiosa permite compreender o sentido do universalismo judaico. Uma verdade é universal quando está aberta a todos. (...) Eleição que não está feita de privilégios, mas de responsabilidades ${ }^{21}$.

${ }^{18}$ LEVINAS, Emmanuel. Totalidade e infinito. Ensaio sobre a exterioridade. Trad.: José P. Ribeiro. Lisboa: Edições 70, 1980. p. 67.

${ }^{19}$ LEVINAS, Emmanuel. Ética e infinito. Diálogos com Philippe Nemo. Trad.: João Gama. Lisboa: Edições 70, 1982b. p. 112.

${ }^{20}$ LEVINAS, Emmanuel. Ética e infinito. Diálogos com Philippe Nemo. Trad.: João Gama. Lisboa: Edições 70, 1982b. p. 112.

${ }^{21}$ El rol desempeñado por la ética em la relación religiosa permite comprender el sentido del universalismo judio. Una verdad es universal cuando está abierta a todos.(...) Elección 
É nesse contexto que, para Lévinas, o sentido religioso universal do judaísmo e, neste caso das religiões em geral, só encontra justificativa pela relação ética de responsabilidade e serviço ao outro e não nos dogmatismos presentes nas mesmas. Esta ideia perpassa o pensamento do filósofo sobre a religião, com todos seus pressupostos éticos o que a torna infinita. Estes pressupostos, ao ampliar a concepção de religião, garantem a sua originalidade e a liberta do logocentrismo, além de sinalizar para outro modo de conceber a ideia de Deus.

\section{A ideia de Deus}

Na concepção segundo a qual a ética é o sentido original da religião percebe-se que o outro em sua alteridade adquire uma dimensão transcendente, o que sem dúvida suscita questionamentos, tais como: o outro é Deus? Se a religião é infinita e está para além da ontologia, que lugar ocupa Deus no pensamento? E ainda, é possível pensar Deus fora da ontologia?

As respostas para esses questionamentos ocupam um lugar de destaque, pois representam uma proposta de saída da ontologia, conforme a abordagem de Lévinas que se segue:

o progresso não levou a filosofia ocidental a ultrapassar completamente o ser. Apesar de ter descoberto, para além das coisas - modelo primeiro do ser - os domínios do ideal, da consciência e do devir, ela foi incapaz de privá-los de existência, pois todo o mérito de sua descoberta consistia precisamente em atribuí-los a ela. $\mathrm{O}$ ontologismo, em sua mais abrangente significação, permanecia o dogma fundamental de todo o pensamento ${ }^{22}$.

Esta citação aponta na direção daquilo que o filósofo considera aprisionamento de Deus ao ser, como se o Sagrado pudesse ser contido dentro das categorias racionais. Mais adiante fica clara sua crítica a esta pretensão da razão, ao dizer que

Para além do pensamento contemplativo, a teoria é no fundo o comportamento daquele que carrega eternamente o estigma da existência: ela é es-

que no está hecha de privilégios, sino de responsabilidades. (LEVINAS, Emmanuel. Dificil Libertad. Ensayos sobre el judaismo. Trad.: Juan Haidar. Madrid: Caparrós Editores, 2004. p. 41).

${ }^{22}$ et cependant le progrès n' a pás amené la philosophie occidentale à dépasser entièrement l'être. Lorsqu'elle découvrit au-delà des choses - modèle premier de l'être - les domaines de l'idéal, de la conscience et du devenir, elle fut incapable de les priver d'existence,car tout le bénéfice de sa découverte consistait précisément à la leur attibuer. L'ontologisme sous sa signification la plus large restait le dogme fondamental de toute pensée. (LEVINAS, Emmanuel. De L'évasion. Paris: Fata Morgana, 1982a. p. 124). 
sencialmente submissa ao existente e, quando não parte do ser, vai ao seu encontro. É a impotência diante do fato consumado. ${ }^{23}$

Esse pensamento indica a ruptura que precisa acontecer, para que Deus não fique cativo da razão, como se fosse apenas mais um ser ou ente finito. É nesse sentido que ele inverte a lógica do pensamento, em que não é o pensamento quem pensa Deus, mas sim Deus que vem ao pensamento. Nesse ponto, percebe-se que a concepção de Lévinas aproxima-se do pensamento cartesiano, considerando que a contribuição do pai da filosofia moderna está na ruptura da consciência, ruptura que não é recalcamento no inconsciente, mas desembriaguez ou despertar ${ }^{24}$.

Lévinas reconhece, como se pode constatar, o avanço dado por Descartes no que tange à concepção de Deus. Isto sinaliza, inclusive, na direção de uma resposta para os questionamentos anteriores em que a ideia de Deus antecede ao próprio pensar. Chega-se assim, ao ponto chave da filosofia de Lévinas sobre Deus, em que sua crítica à ontologia não se dirige apenas à razão enquanto fundamento da filosofia, mas também à teologia que, ao se apropriar do pensamento filosófico, enclausura Deus no Ser, ou transforma-O num simples ente restrito ao pensamento.

Em Lévinas, Deus ao mesmo tempo antecede ao pensamento como também está para além da ideia concebida sobre Ele. Posição claramente contrária àquela concebida tradicionalmente na filosofia e na teologia, se é que nesta perspectiva as duas possam ser separadas. Por exemplo, ao interpretar a concepção heideggeriana de Ser, Lévinas tece a seguinte consideração:

Para Heidegger, a compreensão do ser na sua verdade foi imediatamente recoberta pela sua função de fundação universal dos entes por um ente supremo, por um fundador, por Deus. O pensamento do ser, o ser na sua verdade, torna-se saber ou compreensão de Deus: teologia. A filosofia européia do ser torna-se teologia. ${ }^{25}$

Grosso modo, para Lévinas não basta uma ruptura com o pensamento voltado e votado à ontologia, é preciso também romper com todos os pensamentos que assumiram o discurso da ontologia, enclausurando-se

${ }^{23}$ D'ailleurs la pensée contemplative, la théorie est dans son fond le comportement de celui qui porte à jamais le stigmate de l'existence : elle est essentiellement soumise à l'existant et quand elle ne part pas de l'être elle va au-devant de lui. C'est l'impuissance devant le fait accompli.( (LEVINAS, Emmanuel. De L'évasion. Paris: Fata Morgana, 1982a. p.125). ${ }^{24}$ LEVINAS, Emmanuel. Deus, a morte e o tempo. Trad.: Fernanda Bernardo. Coimbra: Almedina, 1993. p. 228.

${ }^{25}$ LEVINAS, Emmanuel. Deus, a morte e o tempo. Trad.: Fernanda Bernardo. Coimbra: Almedina, 1993. p. 137. Para aprofundar este assunto, confira: RIBEIRO JÚNIOR, Nilo; MORO, VÁZQUEZ Ulpiano. A gênese da ética e da teologia na filosofia de Emmanuel Levinas. 1999. 69f. Tese de Doutorado - Centro de Estudos Superiores da Companhia de Jesus, Faculdade de Teologia. p. 15; e, PAIVA, Márcio Antônio. Subjetividade e infinito: o declínio do cogito e a descoberta da alteridade. Síntese: Revista de Filosofia, Belo Horizonte, n. 88, p. 213-231, maio 2000. p. 226. 
em si mesmos, o que é denominado pelo filósofo de onto-teo-logia ${ }^{26}$. Representativamente, Theo se vê entre onto e logos aprisionado como um ser ou um ente qualquer. Como se percebe a possibilidade de se pensar Deus fora do ser traduz uma ruptura com a tradição da filosofia, o que historicamente a teologia não conseguiu produzir, já que desde sua origem, o ser esteve presente como que limitando o ilimitável, reduzindo o irredutível.

\section{Deus enquanto vestigio}

A tradição fundada sob a égide da razão fez do conhecimento uma propriedade particular, desconsiderando toda e qualquer outra possibilidade de se conhecer. É o que aconteceu com a teologia, ao racionalizar a ideia Deus, consolidou-se como a única capaz de pensar e falar sobre Deus. Lévinas rompe com este absolutismo e para além de toda síntese e de todo enclausuramento conceitual, aponta para uma concepção de Deus que ultrapassa o pensamento humano, inclusive a teologia. Para ele:

a realidade objetiva de Deus rompe com a sua realidade formal de cogitação - e tal é talvez o que, avant la lettre, inverte a validade universal e o caráter original da intencionalidade. Deus escapa à estrutura do cogito cogitatum e significa o que não pode ser contido. É neste sentido que a idéia de Deus rompe com o pensamento, que permanece sempre sinopse ou síntese, que fecha sempre numa presença ou re-presenta, que reconduz à presença ou deixa ser. ${ }^{27}$

Percebe-se nesta citação que, mesmo reconhecendo a contribuição de Descartes, a concepção levinasiana de Deus está para além desta. Lévinas mantém sua coerência filosófica e, da mesma forma que a ética precede a ontologia e a religião precede a razão, Deus também precede o pensamento. Isto é, Deus está para além de todas as representações e das idéias que queiram pensá-Lo, já que não é o pensamento que pensa Deus, mas Deus que vem ao pensamento.

Num dos trechos mais perspicazes do filósofo sobre o assunto, ele explicita sua concepção sobre Deus, assim:

Pode-se propor a questão da divindade do Deus Uno como se propõe a questão da humanidade do homem? O Uno tem um gênero? Pode-se pensar a divindade de Deus independentemente de Deus, como o ser se pensa independentemente do Ente? Todo o problema consiste precisamente em se

${ }^{26}$ Vale dizer que este termo é de origem heideggeriana, conforme descrito em: LEVINAS, Emmanuel. Deus, a morte e o tempo. Trad.: Fernanda Bernardo. Coimbra: Almedina, 1993. p. 135.

${ }^{27}$ LEVINAS, Emmanuel. Deus, a morte e o tempo. Trad.: Fernanda Bernardo. Coimbra: Almedina, 1993. p. 228-229. 
perguntar se Deus se pensa como o ser ou como o mais além. Inclusive se a divindade de Deus se enuncia graças à astúcia da linguagem, será preciso imediatamente acrescentar ao ser, que designa a divindade, o advérbio de modo supremo. (...) ‘O Infinito é para si mesmo sua ideia' ${ }^{28}$

Deus é a própria ideia de Deus, ou seja, não é o pensamento que detém esta ideia, mas ela mesma, por si mesma que se oferece ao pensamento com toda sua infinitude, sem a possibilidade deste, de enclausurá-la. $\mathrm{O}$ que é Deus então para Lévinas? Diante da impossibilidade da filosofia, a teologia e as ciências em geral oferecerem uma resposta plausível, o filósofo deixa uma pista para se responder a esta questão. A riqueza de sua linguagem desemboca no sentido de Deus que é vestígio, ou melhor, que se apresenta apenas como vestígio ao pensamento, o que explica a impossibilidade deste de abarcá-Lo. De acordo com o filósofo

é uma ideia que significa, mas por uma significância anterior à presença, a toda presença, anterior a toda origem na consciência e, assim, an-árquica, acessível no seu vestígio; ideia que significa por uma significância mais antiga que sua exibição, que não se esgota na exibição, que não tira seu sentido de sua manifestação, rompendo assim com a coincidência do ser e do aparecer em que, para a filosofia ocidental, reside o sentido ou a racionalidade, rompendo a sinopse..$^{29}$

Como se vê, Deus, na sua dimensão infinita, apresenta-se à consciência apenas como vestígio, sem a possibilidade de o pensamento sintetizá-lo ou explicá-lo. É nessa perspectiva que a transcendência de Deus é livre e se dá ao pensamento a partir daquilo que lhe é exterior, que lhe vem de fora, do alto, enfim, de si mesma, sem que o pensamento possa entender as razões, até porque não há uma razão. Luiz Carlos Susin explicita esta condição impotente da razão e do pensamento sobre a transcendência de Deus, ao afirmar que

Deus é somente 'Ele': O infinito é alteridade inassimilável, diferença absoluta em relação a tudo o que se mostra, ao que se sinaliza ou se simboliza, se anuncia e se rememora (...) Seu passado imemorial não é extrapolação da permanência (durée) humana mas a anterioridade original ou a ultimidade original de Deus em relação a um mundo que não pode alojá-lo. ${ }^{30}$

${ }^{28}$ La cuestión de la divinidad del Dios-Uno ipuede plantear-se como se plantea la cuestión de la humanidad del hombre? ¿Tiene el Uno un gênero? ¿Puede pensarse la divinidad de Dios independientemente de Dios, como el ser se piensa independientemente del Ente? Todo el problema consiste precisamente en preguntarse si Dios se piensa como el ser o como el a más allá. Incluso si la divinidad de Dios se enuncia gracias a la astúcia del lenguaje, será preciso inmediatamente anãdir al ser, que designa la divinidad, el adverbio de modo supremo.'El Infinito es para sí mismo su idea'. (LEVINAS, Emmanuel. De Otro Modo que ser: o más allá de la esencia. Salamanca: Ediciones Sígueme, 2003. p. 162). ${ }^{29}$ LEVINAS, Emmanuel. De Deus que vem à ideia. Trad.: Pergentino Stefano Pivatto. Petrópolis: Vozes, 2002. p. 97.

${ }^{30}$ SUSIN, Luiz Carlos. O homem messiânico: uma introdução ao pensamento de Emmanuel Lévinas. Petrópolis: Vozes, 1984, p. 456. 
Visto por este prisma e levando-se em conta que a primazia da ética, conforme a propõe o filósofo lituano, pressupõe o reconhecimento do outro em sua alteridade - o que garante ao outro um lugar privilegiado - devese perguntar: a prioridade concedida por Lévinas ao outro não o transforma em Deus? Esta pergunta aponta mais uma vez para a incomensurabilidade da linguagem que ultrapassa as sínteses ontológicas. Nesse caso, Lévinas sinaliza para Deus que, enquanto vestígio, não é apenas outro, mesmo que absolutamente Outro, mas é Ele na sua eleidade, terceira pessoa que está para além da relação eu - outro, pois está para além da própria linguagem.

\section{A eleidade $e$ o outro}

De imediato é preciso assinalar que em Lévinas Deus não pode ser tematizado pela razão. Por isso, a prioridade que o outro possui sobre o eu não se estende ao Outro infinito, transcendente, que é Deus. Contudo, é pelo serviço ao outro enquanto responsabilidade que perpassa a relação ética, que o eu pode encontrar-se com o infinitamente Outro. Dessa maneira, somente quando o eu se torna totalmente responsável pela vida, pelo bem-estar, pela existência do outro, sendo-lhe, inclusive submisso, é que Deus se torna acessível.

A partir desse pressuposto, a ideia de Deus presente em Lévinas está para além do pensamento e da ontologia, ou melhor, da onto-teo-logia que, insistentemente, tenta explicar o inexplicável. Nas palavras do filósofo

o Deus da súplica - da invocação - seria mais antigo que o Deus deduzido a partir do mundo ou a partir de uma irradiação qualquer a priori e enunciada em uma proposição indicativa; o velho tema bíblico do homem feito à imagem de Deus toma um sentido novo, mas é a partir do 'tu' e não do 'eu' que esta semelhança se anuncia. O próprio movimento que conduz a outrem conduz a Deus. ${ }^{31}$

Ora, o movimento que conduz a outrem consiste na relação ética na qual o eu é responsável pelo outro, sem poder reivindicar o mesmo por parte do outro em relação a si. Esta disposição pressupõe uma gratuidade, um desinteressamento por parte do eu que, na relação, é interpelado pelo outro a agir eticamente numa abertura infinita para servi-lo. Assim, a relação ética constitui-se no movimento em direção ao outro que conduz o eu em direção a Deus, que se mantém separado do eu, exterior ao pensamento, acessível apenas pela relação de serviço ao outro. Pode-se exprimir, por-

${ }^{31}$ LEVINAS, Emmanuel. De Deus que vem à ideia. Trad.: Pergentino Stefano Pivatto. Petrópolis: Vozes, 2002. p. 199. 
tanto, que $A$ relação ética se torna o lugar onde se faz a experiência de Deus, que não se pode demonstrar dentro de um sistema cognoscitivo, porque está além, mas que se mostra e se revela na responsabilidade, na solicitude e amor para com o Outro ${ }^{32}$.

Dessa maneira a relação ética, ao conduzir o eu a Deus, permite o movimento em que Deus vem à ideia, e que o Infinito se faz presente no finito, sem se tornar com isso, objeto da razão, do pensamento. Segundo Lévinas ${ }^{33}$ $A$ ideia de infinito não é para mim objecto. $O$ argumento ontológico jaz na mutação desse 'objecto' em ser, em independência a meu respeito. Deus é o Outro. Está claro: Deus é o Outro, porém, o outro não é Deus, mesmo que pela relação ética, pela socialidade, ele manifeste a presença de Deus. Sobre este assunto assim se expressa Lévinas: ${ }^{34}$

Haveria uma desigualdade - uma dessimetria - na relação, contrariamente à 'reciprocidade' sobre a qual, sem dúvida de modo errado, insiste Buber. (...) Desigualdade que pode parecer arbitrária; a não ser que ela seja, na palavra endereçada ao outro homem, na ética do acolhimento, o primeiro serviço religioso, a primeira oração, a primeira liturgia, a religião a partir da qual Deus poderia vir ao espírito e a palavra Deus ter feito sua entrada na linguagem e na boa filosofia. Evidentemente, isso não significa que o outro homem deva ser tomado por Deus ou que Deus, o Eterno, se encontre simplesmente em algum prolongamento do Tu.

É nessa desigualdade da relação ente o Eu e o Tu como representação do outro que, Deus enquanto vestígio se apresenta e se torna acessível como terceira pessoa, ou seja, como um Ele que não se confunde com o outro e, muito menos, se dá a conhecer a partir do eu. Deus enquanto Ele mantém sua Eleidade separada do eu e do outro, ou seja, sua transcendência continua transcendente, exterior e livre do pensamento, mesmo que em sua dimensão infinita se faça presente no finito. Essa presença, no entanto, já é uma presença ausente, visto que o finito não pode mensurá-la e nem captá-la no tempo e no espaço.

Uma descrição bastante elucidativa sobre a Eleidade é feita por Susin, que diz:

Ele que não se recupera num $\mathrm{Tu}$, mas Ele retirado irreversivelmente sem jamais se fazer presente, não é uma ausência negativa. É ausência significativa: a sua desmesura e o seu infinito, que o presente do mundo não contém, respeitam o eu separado sem ocupar espaço neste mundo, mas não o

${ }^{32}$ PAIVA, Márcio Antônio. Subjetividade e infinito: o declínio do cogito e a descoberta da alteridade. Sintese: Revista de Filosofia, Belo Horizonte, n. 88, p. 213-231, maio 2000. p. 227.

${ }^{33}$ LEVINAS, Emmanuel. Totalidade e infinito. Ensaio sobre a exterioridade. Trad.: José P. Ribeiro. Lisboa: Edições 70, 1980. p. 189.

${ }^{34}$ LEVINAS, Emmanuel. De Deus que vem à ideia. Trad.: Pergentino Stefano Pivatto. Petrópolis: Vozes, 2002. p. 201-202. 
deixam indiferente: na eleidade, Ele envia o outro. A sua renúncia de si mesmo coincide assim com o bem que não se exibe, mas envia o outro na abundância à bondade. (...) Por isso o infinito e o bem são 'Ele' ${ }^{35}$

Pela relação ética, portanto, o eu se vê face-a-face com o outro, a eleidade se faz presente mesmo não sendo o outro, por se manter separado do eu. Ora, o outro é quem revela a presença de Deus para que o eu se coloque desinteressadamente a seu serviço, sem, contudo, transformar-se em Deus. Assim sendo, $O$ 'movimento' deve, pois ser pensado 'do além para cá', e não de cá para o além, que coincide com o fato de que o bem me amou antes que eu o amasse, e me deixou seu dom - o outro - para que eu possa amar. ${ }^{36}$

Nesse sentido, em Lévinas, mais que falar de Deus ou pensar Deus, é preciso colocar-se a serviço do outro desinteressadamente, já que esta é a condição para estabelecer a relação com Ele. Nas palavras de Ribeiro Júnior ${ }^{37}$ A relação ética é o lugar da revelação/palavra/lei de Deus. O único acesso a Deus passa necessariamente pela responsabilidade pelo outro homem. Mària Serrano (1997, p. 32-33) também aponta a ética como a via que dá acesso a Deus, ao escrever que a espera da revelação em chave ética é a única maneira de se ter acesso à transcendência. Assim, pois, não podemos falar de Deus; só podemos dar testemunho d'Ele. ${ }^{38}$

O testemunho, nesse caso, sustém-se no pleno comprometimento do eu para com o outro, sem ressalvas ou interesses por parte do eu, já que o outro, pela relação ética, precede toda e qualquer racionalidade que tente manter a sua primazia. É o que revela Lévinas:

O testemunho não vem acrescentar-se como expressão, informação ou sintoma, e não se refere a não sei que experiência do Infinito. Em momento algum o Infinito foi tematizado. Não há experiência do Infinito que não seja tematizável. Mas pode haver relação com Deus na qual o próximo é um momento indispensável. A Bíblia deixa entendê-lo: conhecer Deus é fazer justiça ao próximo. ${ }^{39}$

\footnotetext{
${ }^{35}$ SUSIN, Luiz Carlos. O homem messiânico: uma introdução ao pensamento de Emmanuel Lévinas. Petrópolis: Vozes, 1984, p. 244.

${ }^{36}$ SUSIN, Luiz Carlos. O homem messiânico: uma introdução ao pensamento de Emmanuel Lévinas. Petrópolis: Vozes, 1984, p. 245.

37 RIBEIRO JÚNIOR, NILO. Sabedoria de amar: a ética no itinerário de Emmanuel Lévinas. São Paulo: Loyola, 2005. p. 117.

${ }^{38}$ la espera de la revelación en clave ética es la única manera de acceder a la trascendencia. Así, pues, no podemos hablar de Dios; sólo podemos dar testimonio de El. (MÀRIA SERRANO, Josep F. E. Lévinas: entre el deseo de pan y el deseo de Dios. Barcelona, Institut Teologia Fonamental Sant Cugat Del Valles, 1997. p. 33).

${ }^{39}$ LEVINAS, Emmanuel. Deus, a morte e o tempo. Trad.: Fernanda Bernardo. Coimbra: Almedina, 1993. p. 213-214.
} 
Verifica-se, então, que o outro pelo qual o eu é responsável sem mesmo saber quem ele é, manifesta a presença de Deus transcendente e infinito na finitude humana, sem, por isso, transformar Deus em um outro imanente, humano. Ou seja, a transcendência infinita de Deus permanece preservada, já que Deus é o Outro, mas o outro não é Deus. Para exemplificar uma vez mais a importância desta distinção, vale retomar os argumentos de Luiz Carlos Susin ${ }^{40}$ conforme descrito abaixo:

o equívoco entre Deus e o outro, que eu não posso desfazer intelectualmente por causa da cumplicidade na alteridade que eu não alcanço com meu saber, é - como já acenamos mais de uma vez - um equívoco que se desfaz na relação ética. (...) Nesta distinção 'moral', Deus - Ele e bem - não tem exigências morais para si, é o outro homem a alteridade mais exigente que Deus.

Por essa citação, fica clara a abertura infinita de Deus, o que explicita o sentido de religião entendida como ética, já que Deus não faz nenhuma exigência moral ao eu que esteja voltado para $\mathrm{Si}$, até porque em sua infinitude Ele não precisa desse serviço do eu. Ao contrário, o outro, na sua alteridade tradicionalmente negada, precisa ser reconhecido e servido para além dos interesses do eu. Por isso Lévinas concede-lhe a primazia em relação ao eu, e aponta o amor sem concupiscência por parte do eu como condição para se alcançar o absolutamente Outro.

Assim sendo, a manifestação de Deus ocorre como descreve Lévinas, no rosto do outro enquanto expressão da nudez e fragilidade de quem clama por justiça, por um pedaço de pão, enfim, por um amor desinteressado da parte do eu. Na riqueza dessa linguagem o rosto revela a presença de Deus, o que equivale a dizer que, mesmo o outro não sendo Deus, em seu Rosto é que se manifesta a infinitude de Deus.

\section{O Rosto}

Para Lévinas Deus está para além da idéia de Deus e, consequentemente, para além da ontologia e sua pretensa capacidade de representá-Lo, explicáLo e reduzi-Lo a objeto. Entretanto, na medida em que pela tradição o que não passa pelo crivo da razão não é válido, um questionamento recorrente no pensamento de Lévinas diz respeito à epifania de Deus, a saber: como o homem consegue percebê-Lo?

A resposta do ponto de vista levinasiano confirma uma vez mais a originalidade de sua filosofia como saída do eu em direção à ética, já que a epifania de Deus se dá pela relação face-a-face entre eu e o outro, especialmente o pobre, identificado com o órfão, a viúva, o estrangeiro. Isto significa que o desvelar do rosto que se apresenta aos olhos do eu, não

${ }^{40}$ SUSIN, Luiz Carlos. O homem messiânico: uma introdução ao pensamento de Emmanuel Lévinas. Petrópolis: Vozes, 1984, p. 250-251. 
retrata mera manifestação que pode ser apreendida como fenômeno ou pensada como acontecimento. Para Lévinas ${ }^{41}$ a significação ou a inteligibilidade não está ligada à identidade do Mesmo que permanece em si, mas no rosto do Outro que faz apelo ao Mesmo.

Como entender então a epifania de Deus no pensamento de Lévinas? Uma descrição bastante clara desse assunto é feita por Luiz Carlos Susin ${ }^{42}$ conforme se lê a seguir:

A epifania do Olhar deve ser entendida de modo inteiramente diverso da manifestação (incluindo na 'manifestação' todas as nuances de mostração, aparecimento, exibição, etc. estabelecidas na fenomenologia), está em dimensão diversa do fenômeno e do reino fenomênico: (...) o Olhar (...) me atinge diretamente porque penetra sem mediações e, no entanto, permanece absolutamente exterior ao mundo, de exterioridade não espacial, como um estranho não-mundo no mundo.

Nota-se que a epifania de Deus apresenta-se ao olhar humano através do rosto como uma convocação ao eu para servir e responder por tudo que porventura aconteça ao outro. Pelo rosto evidencia-se o sentido da relação ética como origem da religião na qual Lévinas concebe a possibilidade de o eu transcender suas limitações para, em sua responsabilidade para com o outro, ter acesso a Deus. René Bucks ${ }^{43}$ retrata este aspecto da filosofia levinasiana ao salientar que

A relação ética realiza uma verdadeira transcendência, um salto para aquilo que é exterior e que de forma alguma o sujeito possa prever ou antecipar pela razão. (...) O outro não é a encarnação de Deus, mas precisamente pelo seu rosto em que está desencarnado, a manifestação da altura em que Deus se revela.

Pelas palavras de Bucks se confirma que o rosto revela a presença de Deus naquele que está próximo e pelo qual o eu deve responder incondicionalmente. Como para Lévinas o rosto não se restringe à face humana - a apenas uma parte anatômica do corpo - mas sim a todo o corpo, pois $O$ rosto não é o conjunto formado por um nariz, uma frente, uns olhos, etc. É tudo isso certamente, porém adquire a significação do rosto pela nova dimensão que abre a percepção de um ser. ${ }^{44}$

\footnotetext{
${ }^{41}$ LEVINAS, Emmanuel. Totalidade e infinito. Ensaio sobre a exterioridade. Trad.: José P. Ribeiro. Lisboa: Edições 70, 1980. p. 83.

${ }^{42}$ SUSIN, Luiz Carlos. O homem messiânico: uma introdução ao pensamento de Emmanuel Lévinas. Petrópolis: Vozes, 1984, p. 207.

${ }^{43}$ BUCKS, René. A Bíblia e a ética: a relação entre a filosofia e a sagrada escritura na obra de Emmanuel Levinas. São Paulo: Loyola, 1997. p. 108.

${ }_{44}$ "El rostro no es el conjunto formado por una nariz, una frente, unos ojos, etc. Es todo eso ciertamiente, pero adquiere la significación de rostro por la nueva dimensión que abre en la percepción de un ser". (LEVINAS, Emmanuel. Dificil Libertad. Ensayos sobre el judaismo. Trad.: Juan Haidar. Madrid: Caparrós Editores, 2004. p. 25).
} 
Na significação do rosto, verifica-se a exterioridade que permite a relação do eu com o infinito a partir do infinito e não do pensamento. Nesse sentido o rosto, na sua dimensão transcendente é a epifania de Deus que se dá ao mundo sem poder ser captado pelo mundo em sua finitude. Nesse sentido, a palavra 'epifania' significa de alguma forma uma entrada no mundo, mas a partir de uma dimensão de 'altura' ${ }^{45}$. Por esse viés, é que o rosto enquanto expressão da responsabilidade para com o outro, não cessa de eticamente convocar o eu às suas obrigações. Eis o que profere Lévinas: ${ }^{46}$

O rosto em que outrem se volta para mim não se incorpora na representação do rosto. Ouvir a sua miséria que clama justiça não consiste em representarse uma imagem, mas em colocar-se como responsável, ao mesmo tempo como mais e como menos do que o ser que se apresenta no rosto. Menos, porque $\mathrm{o}$ rosto me chama às minhas obrigações e me julga. $\mathrm{O}$ ser que nele se apresenta vem de uma dimensão de altura, dimensão da transcendência onde pode apresentar-se como estrangeiro sem se opor a mim (...).

Eis aí a possibilidade do encontro com Deus e, tendo em vista que para Lévinas (1982b, p. 79) a relação com o rosto é, num primeiro momento, ética, então, a epifania de Deus se torna acessível, mesmo que este não seja visto. É o que Lévinas ${ }^{47}$, por exemplo, diz a Philippe Nemo: no acesso ao rosto, há certamente também um acesso à ideia de Deus. Como se vê, para o filósofo lituano, o cogito não produz a ideia de Deus, mas esta que se reproduz no cogito, vinda do infinito sem fazer morada no finito, uma vez que o cogito não pode contê-la, precisamente porque ele não é termo, mas Infinito. ${ }^{48}$

Nessa perspectiva, o rosto, na sua exposição sem máscaras e disfarces, revela a face de Deus em toda sua humildade e pobreza, mas também em toda sua glória infinita, reflexo da nudez que desvela a epifania da ética em sua transcendência. Como a ética não cessa de convocar o eu à bondade e ao serviço para o outro a glória resplandece na exposição e na expressão da exposição, ou seja, no gesto ético da imolação..$^{49}$ Eis por que o rosto, enquanto epifania da ética faz-se abertura para a transcendência e o infinito. Epifania de Deus que supõe uma proximidade do infinito como vestígio, que não é uma palavra a mais: é a proximidade de Deus no rosto do meu próximo ${ }^{50}$.

${ }^{45}$ SUSIN, Luiz Carlos. O homem messiânico: uma introdução ao pensamento de Emmanuel Lévinas. Petrópolis: Vozes, 1984, p. 206.

${ }^{46}$ LEVINAS, Emmanuel. Totalidade e infinito. Ensaio sobre a exterioridade. Trad.: José P. Ribeiro. Lisboa: Edições 70, 1980. p. 192-193.

${ }^{47}$ LEVINAS, Emmanuel. Ética e infinito. Diálogos com Philippe Nemo. Trad.: João Gama. Lisboa: Edições 70, 1982b. p. 83.

${ }^{48}$ LEVINAS, Emmanuel. De Deus que vem à ideia. Trad.: Pergentino Stefano Pivatto. Petrópolis: Vozes, 2002. p. 220.

${ }^{49}$ SUSIN, Luiz Carlos. O homem messiânico: uma introdução ao pensamento de Emmanuel Lévinas. Petrópolis: Vozes, 1984, p. 402.

${ }^{50}$ LÉVINAS, Emmanuel. Entre nós: ensaios sobre a alteridade. 2.ed, Petrópolis: Vozes, 2005. p. 88 . 
Retoma-se, assim, o sentido de Deus como vestígio, ou seja, como Aquele que não é conhecido, pensado e visto - a não ser na nudez do rosto do próximo - que ao mesmo tempo, está próximo e distante do eu, vez que também não pode ser assimilado pelo pensamento. Por isso o eu deve desenraizar-se de si mesmo, pois, como sinaliza Lévinas: ${ }^{51}$

A nudez do rosto é um desenraizamento do contexto do mundo, do mundo que significa como contexto. $\mathrm{O}$ rosto é precisamente aquilo pelo qual se produz originalmente o acontecimento excepcional do em-face, que a fachada do prédio e das coisas não faz senão imitar.

Chega-se, pois, ao ponto em que pela nudez do rosto a epifania da ética designa a saída da ontologia proposta por Lévinas em direção à alteridade do outro, em meio à sua abertura para o infinito. Porém, o risco de se retornar ao saber absoluto e ao fechamento da ontologia sempre se impõe o que implica a necessidade constante de perpetuar o processo da evasão. Ante essa possibilidade, o filósofo lituano sugere a importância de sempre desdizer aquilo que foi dito, como recurso para se evitar os absolutismos do saber.

\section{O Dizer como glória do Infinito}

A leitura e estudo dos escritos de Lévinas revelam uma constante preocupação do autor com os dogmatismos da filosofia que, ao restringir o conhecimento à razão, fecha as portas para outras possibilidades de saber. É neste ponto que a proposta do filósofo demonstra toda a sua originalidade, numa guinada que leva à abertura para a alteridade do outro na sua transcendência infinita, tendo como pressuposto a relação ética, que se dá no movimento da própria vida e não no conhecimento estático do ser. Em sendo assim, a ética enquanto exigência de responsabilidade do eu pelo outro, deve estar aberta ao dizer constante da alteridade como forma de se superar o dito da ontologia.

Marcelo Pelizzoli ${ }^{52}$ destaca que em Lévinas, o Dizer transido para a temporalidade da alteridade traz à tona a diacronia inerente a uma 'síntese passiva' - 'sentida' nos elementos da sensibilidade — da subjetividade, ou o Dizer. Para que isto ocorra, é preciso levar em consideração que o dizer da alteridade, conforme proposto por Lévinas, ultrapassa o diálogo $E u-T u$, numa abertura para a relação infinita entre eu e o outro. Nas palavras do filósofo

o Dizer não é compreendido como diálogo, mas como testemunho do infinito àquele a quem infinitamente eu me abro. Na relação com outrem, significa esta dimensão de testemunho, que não repousa num conhecimento

${ }^{51}$ LÉVINAS, Emmanuel. Entre nós: ensaios sobre a alteridade. 2.ed, Petrópolis: Vozes, 2005. p. 89.

${ }_{52}$ PELIZZOLI, Marcelo. Acerca do (des) encontro: Husserl, Heidegger e Lévinas. Veritas: Revista de Filosofia, Porto Alegre, v. 47, n. 2 , p. 145-158, jun. 2002. p. 151.

Síntese, Belo Horizonte, v. 37, n. 119, 2010 
prévio. (Limitar o testemunho pelo conhecimento prévio far-nos-ia cair de novo na ontologia) ${ }^{53}$. (LÉVINAS, 1993, p. 204-205).

O dizer da alteridade, portanto, é o que em sua abertura ética torna possível a saída da ontologia, rompendo com a sincronia do dito. Ele supõe a diacronia da socialidade que deve pautar as relações humanas em sua dinamicidade, sem se submeter às explicações sistemáticas da razão. Pelizzoli (2002, p. 151) afirma que $A$ diacronia do Dizer é significância por excelência; ela viria antes do próprio enunciado do ser enquanto ser. Esta condição pré-original do dizer faz com que o dito seja desdito constantemente pelo dizer numa perspectiva ilimitada, por isso, ética. Marcelo Fabri (1997, p. 125) ao comentar o papel do dizer conjectura que

o Dizer é uma des-situação do sujeito. Por ele o sujeito cessa de ser o que é: expõe-se ao Outro, arrancando-se de si mesmo nessa exposição. O Dizer é expulsão de toda morada, de toda habitação. Trata-se de uma verdadeira extradição, de uma evasão de si como expulsão sem retorno. O Dizer é para nós um permanente desencantar da Essência, é uma dessacralização do seu locus e do sentido da linguagem como morada do ser.

Pela interpretação de Fabri, depreende-se que o dizer com toda sua significância ética cumpre uma função clara de manter o dito desperto para não incorrer no risco de retorno à ontologia. A vigilância, portanto, deve ser permanente numa evasão sem retorno. Por esse viés é que o dizer também deve ser desdito permanentemente para em seu constante desdizer romper com o dito da ontologia. Nas palavras de Lévinas é a significação do Dizer que vai mais além da essência reunida no Dito, a que poderá justificar a exposição do ser ou da ontologia ${ }^{54}$.

Clareia-se a importância do dizer como aquele que é responsável por desalojar o dito de sua morada e, que deve se constituir como principal característica da filosofia que como sabedoria do amor deve reconhecer outras formas de saber, para além do próprio saber. Essa nova perspectiva aponta para a filosofia que não se reduz ao conhecimento racional, e que se descortina para a glória do infinito. Este aspecto da filosofia levinasiana, possibilita à filosofia questionar-se a si mesma. Aliás, é tal capacidade originária da filosofia que propicia a Lévinas não romper definitivamente com a mesma, conforme o descreve Luiz Carlos Susin: ${ }^{55}$

Mas se o pensamento e a filosofia são estruturas de universalidade, somente cumprem sua tarefa na obediência ao que lhes precede e não é absorvido no pensamento e na filosofia. Por isso, Lévinas acena com bem maior

${ }^{53}$ LEVINAS, Emmanuel. Deus, a morte e o tempo. Trad.: Fernanda Bernardo. Coimbra: Almedina, 1993. p. 204-205.

${ }^{54}$ es la significación del Decir que va más allá de la esencia reunida en lo Dicho, la que podrá justificar la exposición del ser o la ontologia. (LEVINAS, Emmanuel. De Otro Modo que ser: o más allá de la esencia. Salamanca: Ediciones Sígueme, 2003. p. 87).

${ }^{55}$ SUSIN, Luiz Carlos. O homem messiânico: uma introdução ao pensamento de Emmanuel Lévinas. Petrópolis: Vozes, 1984, p. 128. 
frequência para o papel diaconal da filosofia na recondução ou redução do

Dito ao Dizer, através da possibilidade do desdito, da crítica, da ruptura.

A importância dessa citação está no reconhecimento de que Lévinas não nega o valor da filosofia e da linguagem, mas apenas aponta para outra forma de se concebê-las. Por sua ótica, elas só cumprem seus papéis quando questionam a si mesmas e reconhecem suas limitações, abrindo-se para o conhecimento que lhes é exterior. Eis a abertura que permite ao dizer ir para além do dito para assumir a dimensão de altura que o associa à ética. O dizer adquire, assim, a qualidade de excedente, já que não pode ser abarcado, sintetizado, enfim, conceituado pelo dito.

Retoma-se, assim, o sentido de responsabilidade desinteressada que pela eleição do eu o leva a substituir o outro até em seus erros e dores, numa exposição e disposição que remetem à passividade de quem não visa a seus próprios interesses, visto que o eu jamais consegue quitar sua dívida para com o outro. Lévinas se refere aqui à possibilidade de abertura do sujeito para o infinito na sua condição de refém do outro. Por isso o excesso a que se refere o filósofo diz respeito ao dizer, na sua dimensão infinita de desdizer o dito. Segundo ele:

Responsabilidade pelo outro - por sua miséria e sua liberdade - que não remonta a nenhum engajamento, a nenhum projeto, a nenhum desvelamento prévio em que o sujeito seria posto para si antes de estar-em-dívida. (...) Tal excesso é dizer. [.... ${ }^{56}$

Como excedente, portanto, o dizer assume sua dimensão de transcendência na responsabilidade que se deve ter para com o outro, o que lhe permite quebrar os encantos e feitiços da razão. Nesse contexto, ele adquire uma significação que ultrapassa o sentido do dito em seu dizer fechado. Como descrito por Marcelo Fabri ${ }^{57}$ O Dizer é sinceridade, é testemunho e Glória do Infinito ${ }^{58}$. Todavia, o que a priori pode parecer um privilégio, torna-se uma obrigação, uma responsabilidade incondicional, sem possibilidades de fuga por parte do eu - o que explica sua passividade diante do outro.

A obrigação, neste caso, não surge no próprio eu. Ela é oriunda do infinito, da relação ética que não permite ao eu fechar os olhos diante das necessidades do outro. Como propõe Lévinas: ${ }^{59}$

O que faz o aumento da obrigação é o Infinito, é uma glória, ou o acto de que quanto mais percorrida for a distância, mais resta por percorrer. (...)

\footnotetext{
${ }^{56}$ LEVINAS, Emmanuel. De Deus que vem à ideia. Trad.: Pergentino Stefano Pivatto. Petrópolis: Vozes, 2002. p. 108-109.

${ }^{57}$ FABRI, Marcelo. Desencantando a ontologia: subjetividade e sentido ético em Levinas. Porto Alegre. Edipucrs, 1997. p. 123.

${ }^{58}$ A esse respeito vale conferir: PAIVA, Márcio Antônio. Subjetividade e infinito: o declínio do cogito e a descoberta da alteridade. Síntese: Revista de Filosofia, Belo Horizonte, n. 88, p. 213-231, maio 2000. p. 224-227).

${ }^{59}$ LEVINAS, Emmanuel. Deus, a morte e o tempo. Trad.: Fernanda Bernardo. Coimbra: Almedina, 1993. p. 207.
} 
Esta passividade da passividade, esta dedicatória a outrem é uma sinceridade - e esta sinceridade é Dizer.

Ora, o dizer como testemunho e glória do infinito sinaliza para a abertura à transcendência que em sua ausência e distância, faz-se presente na responsabilidade do eu para com o outro e na impossibilidade de a ontologia conseguir explicá-lo e tematizá-lo. A partir desse pressuposto, vale enfatizar que é pelo testemunho que o dizer rompe com o dito da filosofia para abrir-se à glória do infinito, que concede ao sujeito sua autêntica identidade, ou seja, estar inteiramente à disposição para responder e servir ao outro como outro modo de ser, tendo em vista que

A glória do Infinito é a identidade an-árquica do sujeito desenvolvido sem possível ocultamento, eu determinado à sinceridade, proporcionado sinal ao outro - do qual sou responsável e ante quem sou responsável - desta mesma doação do sinal, é dizer desta responsabilidade: 'eis-me aqui'. ${ }^{60}$

Confirma-se, por esta citação que a proposta de Lévinas é ousada, pois aponta para outras formas de saber que ultrapassam o saber ontológico, numa valorização da vida e do outro que deixam o eu exposto e sem morada fixa. Exposição que implica disposição para enfrentar continuamente o novo que se lhe apresenta no rosto do outro, sem a possibilidade de esboçar nenhuma resposta pronta. Esta imprevisibilidade é o que, para Lévinas, obriga o dizer a sempre desdizer-se, para atingir sua glória de infinito e não se sucumbir aos encantos da razão.

\section{Conclusão}

Na direção da filosofia levinasiana, esta conclusão não tem como objetivo encerrar o assunto, mas apenas tecer algumas considerações sobre a importância do pensamento do filósofo lituano que apontam para uma mudança de paradigmas no âmbito da tradição. O fato de Lévinas utilizar-se da filosofia para elaborar sua proposta consiste numa dessas considerações mais importantes. Isto, porque, em geral, as novas teorias filosóficas costumam primeiramente negar as anteriores. Lévinas pelo contrário, não nega a filosofia e sua história, mas sim sinaliza para um outro modo de pensar que desemboca num outro modo de ser.

É esta novidade que marca a originalidade do pensamento do filósofo e possibilita pela abertura da filosofia o encontro com a ética, com a religião e com a própria filosofia como reconhecimento do outro na sua alteridade

${ }^{60}$ La gloria del Infinito es la identidad an-árquica del sujeto desemboscado sin posible ocultamiento, yo abocado a la sinceridad, aportando signo al otro - del cual soy responsable y ante quien soy responsable - de esta misma donación del signo, es decir, de esta responsabilidad:'heme aqui'. (LEVINAS, Emmanuel. De Otro Modo que ser: o más allá de la esencia. Salamanca: Ediciones Sígueme, 2003. p. 222). 
exterior e infinita, pois, pela relação ética, o eu não percebe primeiro uma ordem vinda do outro que em seguida, é obedecida. É no compromisso ético que a ordem é percebida ${ }^{61}$.

Pela relação ética, portanto, a religião e a filosofia revelam sua dimensão transcendente para na glória do infinito garantir ao dizer a possibilidade de desdizer o dito constantemente. Isto, pois, pelas vias da ética como préoriginária ao pensar, a proposta filosófica de Lévinas transforma a filosofia de amor à sabedoria em sabedoria do amor, o que a permite sempre desdizer-se numa ruptura com os ditos da ontologia.

\section{Referências}

BAILHACHE, Gérard. Le sujet chez Emmanuel Levinas: fragilité et subjectivité. Paris: PUF, 1994.

BUCKS, René. A Bíblia e a ética: a relação entre a filosofia e a sagrada escritura na obra de Emmanuel Levinas. São Paulo: Loyola, 1997.

CIARAMELLI, Fábio. Transcendance et éthique: essai sur Levinas. Bruxelas : ousia, 1989.

DUNCAN, Diane Moira, The Pre-text of Ethics: On Derrida and Levinas. New York: Peter Lang, 2001.

FABRI, Marcelo. Desencantando a ontologia: subjetividade e sentido ético em Levinas. Porto Alegre. Edipucrs, 1997.

FERON, Etienne. De l'idée de transcendance à la question du langage: l'itinéraire philosophique d'Emmanuel Levinas. Grenoble: Jérome Millon, 1992.

LEVINAS, Emmanuel. De Deus que vem à ideia. Trad.: Pergentino Stefano Pivatto. Petrópolis: Vozes, 2002. (De Dieu qui vient à l'idée. Paris: Vrin, 1982).

LEVINAS, Emmanuel. De L'évasion. Paris: Fata Morgana, 1982a.

LEVINAS, Emmanuel. De Otro Modo que ser: o más allá de la esencia. Salamanca: Ediciones Sígueme, 2003. (Autrement qu'être ou au-delà de l'essence. Paris: Kluwer Academic, 1974).

LEVINAS, Emmanuel. Deus, a morte e o tempo. Trad.: Fernanda Bernardo. Coimbra: Almedina, 1993. (Dieu, la mort et le temps. Paris: Grasset, 1993).

LEVINAS, Emmanuel. Dificil Libertad. Ensayos sobre el judaismo. Trad.: Juan Haidar. Madrid: Caparrós Editores, 2004. (Difficile liberté. Essai sur le Judaïsme. Paris: Albin Michel, 1963; 2e édition refondue et complétée, 1976).

LÉVINAS, Emmanuel. Entre nós: ensaios sobre a alteridade. 2.ed, Petrópolis: Vozes, 2005. (Entre nous. Essais sur le penser-à-l'autre. Paris: Grasset \& Fasquelle, 1991).

${ }^{61}$ BUCKS, René. A Bíblia e a ética: a relação entre a filosofia e a sagrada escritura na obra de Emmanuel Levinas. São Paulo: Loyola, 1997. p. 142. 
LEVINAS, Emmanuel. Ética e infinito. Diálogos com Philippe Nemo. Trad.: João Gama. Lisboa: Edições 70, 1982b. (Ethique et infini. Dialogues avec Philippe Nemo. Paris: Librairie Arthème Fayard et Radio France, 1982).

LEVINAS, Emmanuel. Totalidade e infinito. Ensaio sobre a exterioridade. Trad.: José P. Ribeiro. Lisboa: Edições 70, 1980. (Totalité et infini. Essai sur l'extériorité. La Haye: Martinus Nijhoff, 1961).

PAIVA, Márcio Antônio. Subjetividade e infinito: o declínio do cogito e a descoberta da alteridade. Síntese: Revista de Filosofia, Belo Horizonte, n.88, p. 213-231, maio 2000.

PELIZZOLI, Marcelo. O dizer da alteridade além do ser: Levinas e o sentido de conhecimento e linguagem. Veritas: Revista de Filosofia, Porto Alegre, v. 46, n.2, p. 255-263, jun. 2001.

PELIZZOLI, Marcelo. Acerca do (des) encontro: Husserl, Heidegger e Lévinas. Veritas: Revista de Filosofia, Porto Alegre, v.47, n. 2, p. 145-158, jun. 2002.

PIVATTO, Pergentino Stefano. A ética de Lévinas e o sentido do humano - crítica à ética ocidental e seus pressupostos. Veritas: Revista de Filosofia, Porto Alegre, v. 37, n. 147 , p. 125-363, set. 1992.

POIRIÉ, François. Emmanuel Lévinas: ensaio e entrevistas. São Paulo: Perspectiva, 2007.

RIBEIRO JÚNIOR, Nilo; VÁZQUEZ MORO, Ulpiano. A gênese da ética e da teologia na filosofia de Emmanuel Levinas. 1999. 69f. Tese de Doutorado - Centro de Estudos Superiores da Companhia de Jesus, Faculdade de Teologia.

RIBEIRO JÚNIOR, NILO. Sabedoria de amar: a ética no itinerário de Emmanuel Lévinas. São Paulo: Loyola, 2005.

SERRANO, Josep F. Mària. E. Lévinas: entre el deseo de pan y el deseo de Dios. Barcelona, Institut Teologia Fonamental Sant Cugat Del Valles, 1997.

S. PETROSINO. La verità nomade. Milano: Jaca Book, 1980.

S. PETROSINO. Fondamento ed esasperazione. Saggio sul pensare di Emmanuel Lévinas. Genova: Marietti, 1992.

SUSIN, Luiz Carlos. O homem messiânico: uma introdução ao pensamento de Emmanuel Lévinas. Petrópolis: Vozes, 1984.

Endereços dos Autores:

Márcio Antônio de Paiva

Av. Dom José Gaspar, 500 - Prédio 6 sala 141 - Coração Eucarístico

30535-610 Belo Horizonte - MG

drdepaiva@yahoo.com.br

José Geraldo Estevam

Rua Geraldo Emílio Colares, 135 Apt $^{\mathrm{o}}$ 102, Horto,

32604-128 Betim - MG

jgaestevam@yahoo.com.br

406 Síntese, Belo Horizonte, v. 37, n. 119, 2010 